\title{
Soome kooli kitsaskohad
}

\author{
Mare Leino $^{\mathrm{a}}$ \\ a Tallinna Ülikooli ühiskonnateaduste instituut
}

\section{Keltikangas-Järvinen, L., \& Mullola, S. (2016). Maailma parim kool? Tartu: Koolibri.}

Soome haridussüsteemi imetletakse terves maailmas. Tõepoolest, PISA uuringu tulemuste põhjal pole põhjanaabrite kooli headuses põhjust kahelda. Samas kõik ei ole kuld, mis hiilgab: Soome kool pole kaugeltki nii ideaalne, kui mulje põhjal võiks arvata. Helsingi Ülikooli psühholoogiaprofessor Liisa Keltikangas-Järvinen ning tema juhendamisel doktorikraadini jõudnud Sari Mullola üllitasid raamatu „Maailma parim kool?” (ilmunud 2016. aastal ka Eestis Mare Leino tõlkes), kus halastamatu objektiivsusega Soome kooli puudusi päevavalgele tuuakse. Kuna autorite edastatavad sõnumid tuginevad uuringutele ja analüüsile (mitte arvamustele ega oletustele), pole kahtlemiseks põhjust.

Raamatut läbib isiksustevaheliste konfliktide teema. Sari Mullola tõestas 2012. aastal kaitstud doktoritöös, et ligi kolmandikul juhtudest lähtub õpetaja hinde määramisel lapse temperamendist. See tähendab, et meeldivalt käituvad õpilased saavad parema hinde lihtsalt oma olemuse eest. Ebaõigluse määra kumuleerumine aastate jooksul viib olukorrani, kus mõne noore jaoks jääb n-ö vale temperamendi tõttu järgmine haridusetapp kättesaamatuks, samas kui akadeemiliselt vähem võimekas, kuid sileda käitumisega noor pääseb edasi tänu õige mulje jätmise oskusele. Tekib küsimus, kuidas on Soome koolis, mida peetakse ideaalseks haridussüsteemiks, selline olukord võimalik.

Esiteks selgitab õpetaja enda temperament päris paljut, näiteks kasvõi seda, miks mõni õpilane meeldib talle rohkem kui teine, isegi kui kõikide laste teadmised ja motivatsioon on enam-vähem võrdsed. Ideaalis vastab õpetajaskonna temperamendikõver rahvastiku keskmisele jaotusele, st pedagoogide seas peaks olema nii sotsiaalseid, aktiivseid, ujedaid kui ka distantseerunuid proportsionaalselt samal määral kui riigis tervikuna. Kui õpetajate temperamendikõver vastaks rahvastiku keskmisele, oleks 
igal õpilasel võrdselt suur tõenäosus leida mõistmist. Probleemide rohkus koolis paraku osutab, et nii see veel ei ole. Soomlaste uuringust selgus, et konkursisõela läbinud ning ülikooli pääsenud tulevased pedagoogid on märkimisväärselt sotsiaalsed. Rahvastiku keskmisest erineb see seltskond juba kandideerimisetapist alates, igas järgmises voorus lõhe tulevaste pedagoogide ja rahvastiku keskmise vahel üha laieneb. Õpetajakoolituse erialale kandideerija on sotsiaalsem kui keskmine kodanik riigis, katsetele pääsenu on sotsiaalsem kui keskmine kandideerija ning intervjuuvooru läbides pääseb ülikooli õppima veel kõikse sotsiaalsem seltskond. Pole ime, et kõrge sotsiaalsustasemega pedagoog eelistab sarnaste omadustega õpilast. Ujedaid seevastu peetakse pigem probleemseteks.

21. sajandil on ujedusest kujunenud riskifaktor. Julged ja algatusvõimelised lapsed saavad koolis paremat õpetust kui ettevaatlikud või distantseerunud (kelle teadmiste omandamise protsess võib just sel põhjusel kulgeda aeglasemalt). Nimelt nõuavad julged lihtsalt rohkem tähelepanu, nad ei karda kohe küsida, kui mingi tõrge tekib. Kuna sotsiaalsele õpetajale meeldivad suhtlusaltid õpilased, tegelevadki nad nendega meelsamini. Uuringust selgus näiteks, et ujedate õpilaste matemaatikapädevused arenesid esimeses klassis teistest aeglasemalt, kuigi ujedate kognitiivsed võimed ei olnud väiksemad. Seega ei johtunud erinevus õpivalmidusest, vaid õpetusest.

Õpilaste ebaobjektiivse kohtlemise üks põhjuseid on ka Soome õpetajate suur iseotsustamisvabadus. Pedagoog võib ise määrata, millise vastuse eest kui palju punkte ta annab, st kui põhjalikult tuleb vastata, saamaks parimat hinnet. Lisaks võib õpetaja ise otsustada, kas ta koondhinnet tunnistusel veidi kergitab (nt võttes arvesse õpilase tööstiili) või mitte. Niisiis on õpetaja piisavalt iseseisev, et määrata kindlaks, mis faktoreid sisaldab/kajastab lõplik hinne. See tähendab ühtlasi, et subjektiivsus hindamisel on väga suur. Professor Keltikangas-Järvinen rõhutab siinjuures paradoksi: iseseisvus on põhimõtteliselt ju igati tervitatav nähtus, samas temperamendimaailmas (just koolihinnete kontekstis) võib sellega kaasneda probleeme.

Soome õpetajat usaldatakse, ja õpetaja tegelikult seda usaldust tahtlikult ei kuritarvita. Ta annab endast parima igal hetkel. Probleem on lihtsalt selles, et see nn parim johtub tema enda temperamenditüübist. Järelikult sammub Soome üldharidus suunas, kus iseenesest neutraalseid isiksusejooni hinnatakse jõuliselt ja halastamatult.

Raamatu autorid on analüüsinud ka ealiste aspektide mõju. Selgus, et mida vanem oli emakeeleõpetaja, seda vähem ujedus poiste hinnet langetas, st staažika pedagoogi jaoks polnud ujedus negatiivne nähtus. Ilmselt tuleb elukogemus siinkohal kasuks: kogenud õpetaja ei lase end pealiskihist petta. Võimalik, et noored õpetajad esindavad uut põlvkonda, kes varasematest 
jõulisemalt arvab teadvat, milline peaks olema hea inimene - ja 21. sajandil uje kindlasti ei saa olla hea. Autorid loodavad, et aja jooksul lisandub ka praegustele noortele õpetajatele tolerantsust muu hulgas temperamendierinevuste mõistmiseks.

Probleemide korral ei saa eirata ka soolisi faktoreid. Üldistatult võib öelda, et poiste käitumine satub sagedamini koolikultuuriga vastuollu. Kuna poistega peab rohkem riidlema, on neil ka halvem tuju, mis omakorda pärsib õpetaja eduelamust. Kokkuvõttes võib selline suletud, negativistlik ring vormistuda veidi halvemaks hindeks, eriti kui õpetaja ja õpilane on eri soo esindajad. Käärid Soome tüdrukute ja poiste hinnete vahel ongi lääneriikide seas ühed suuremad ja mõnes aines lausa lääneriikide suurimad. Tüdrukute hinnete keskmine on kõikides ainetes kõrgem kui poistel, mh matemaatikas, kuigi sageli kurdetakse, et tüdrukud tunnevad vähest huvi reaalainete vastu. Emakeeles on see soopõhine erinevus suurim: tüdrukute keskmine hinne selles aines oli poiste keskmisest lausa ühe hindepunkti võrra parem. Kui hindamismetoodikast eemaldati (spetsiifiliste statistiliste meetoditega) temperamendijoonte mõju, vähenes tüdrukute ja poiste hinnete erinevus $62 \%$, st üle poole hindepunkti võrra. Tüdrukute keskmine hinne jäi siiski paremaks, kuid käärid vähenesid.

Temperamendipõhine alasooritus võib johtuda lihtsast seigast, nt kui õpilase tööstiil erineb sellest, mida pedagoog ideaalse õpistiili all silmas peab. Üldiselt usub enamik õpetajaid, et just nii, nagu nad ise uusi asju omandavad, ongi kõige õigem viis seda teha. Teistsuguse tööstiiliga õpilasi peetakse veidi ebaharilikeks, võimalik, et süvenevad eelarvamused, mistõttu on sellistel lastel raske saada teadmistele vastavat maksimaalset hinnet. Kui sama olukord kordub nädalast nädalasse, võib rääkida iseennast realiseerivast ennustusest - õpilane enam ei pinguta, kuna hinne on enam-vähem ette teada. Tekib suletud ring: halvasti õpetatavatelt ei oodata midagi erilist, nende töid hinnatakse kriitilisemalt, hinne on pigem halvem kui parem ning lapse õpimotivatsioon raugeb veelgi. Mitmetest uuringutest (Rudasill, Gallagher, \& White, 2010; Van Houtte, 2007) on selgunud, et õpilane saab kontrolltöö eest seda halvema hinde, mida negatiivsemad ootused on õpetajal tema suhtes.

Sisuliselt tähendab õpetatavus plastilisust: mõni laps laseb end täiskasvanul hõlpsamini vormida kui teine (nii koolis kui ka kodus). Õpetatavus käivitab kajaefekti: töökaid lapsi peetakse küpsemateks, täiskasvanulikemateks. Kellele ei meeldiks oma kätetööd imetleda! Meeldivad ju pedagoogile õpetatavad (ehk mõjutatavad) lapsed oluliselt rohkem kui iseteadvad, liiga targad, juba targad või isegi andekad õpilased. Seega on paremat hinnet lihtsam saada lapsel, kes algul ei oska, aga tänu õpetajale 
hakkab oskama. Parema hindega tunnustab/premeerib õpetaja natuke ka iseennast. Iseõppija (või loomult tark) võib jätta ninatarga mulje - ja ülbust tuleks justkui karistada.

Kõigele lisaks võib öelda, et ka suur kollektiiv on riskifaktor. Näiteks tõestasid soomlased, et kooli ja klassi suurus mõjutas õpilase enesetunde ning hinnete vahelist seost eeskätt poiste puhul. Suurtes klassides ja koolides oli halbade hinnetega poistel ka madalam enesehinnang, aga väikekoolides ja/või väikestes klassides mitte. Seega identifitseeris murdeealine poiss end suures koolis või klassis eeskätt õpiedu kaudu - kui hinded olid halvad, langes enesehinnangki. Tüdrukutel, nagu ka väikekoolis ja/või väikestes klassides õppivatel poistel, sellist seost ei ilmnenud. Seos võib olla ka vastupidine: madal enesehinnang soosib suures klassis poiste õpiedutust, aga sellist seost ei teki väikeses klassis. Näiteks on võimalik, et alaväärsustunde tõttu üritavad poisid vähem silma paista, töötavad vähem kaasa, pedagoog seda aga ei märka, sest lapsi on palju, ja nii ta ei suudagi kõikidele lastele samaväärselt tähelepanu pöörata kui väiksemas grupis. Nii või teisiti - poisid on suures kollektiivis rohkem ohustatud kui tüdrukud.

Lühidalt osutas see temperamendiuuring, et Soome suurepärastest PISA tulemustest hoolimata on õpilase temperamendi ja muude personaalsete omaduste seos hinnetega Soomes isegi suurem kui mujal maailmas (Mullola, 2012). Teisisõnu, see, milline on õpilane inimesena, mõjutab ta õpiedu Soomes rohkem kui mujal. Segadus võiks väheneda, kui õpetaja saaks kasutada täiendavat hindamisvahendit, näiteks analüüsida lapse tööstiili, õpiprotsessi iseärasusi ning aktiivsust klassis (või muid temperamendipõhiseid ilminguid). Praegu sisaldub hindes ka mulje, st hinde kaudu üritatakse (sageli alateadlikult) lapse halba käitumist korrigeerida. Lisakriteeriumi juurutamine lisaks objektiivsust, aga see eeldab õpetajahariduse täiendamist temperamendipõhiste teadmistega.

\section{Kasutatud kirjandus}

Keltikangas-Järvinen, L., \& Mullola, S. (2016). Maailma parim kool? Tartu: Koolibri. Mullola, S. (2012). Teachability and school achievement. Is student temperament associated with school grades? Research Report 341. Helsinki: University of Helsinki.

Rudasill, K. M., Gallagher, K. C., \& White, J. M. (2010). Temperamental attention and activity, classroom emotional support, and academic achievement in third grade. Journal of School Psychology, 48(2), 113-134.

doi: http://dx.doi.org/10.1016/j.jsp.2009.11.002

Van Houtte, M. (2007). Exploring teacher trust in technical/vocational secondary schools: Male teachers' preference for girls. Teaching and Teacher Education, 23(6), 826-839. doi: http://dx.doi.org/10.1016/j.tate.2006.03.001 